DOI: 10.19195/2082-8322.10.6

Krzysztof Waraksa

ORCID: 0000-0002-8777-5153

Uniwersytet Wrocławski

Dominika Ziętek

ORCID: 0000-0002-8949-4021

Uniwersytet Wrocławski

\title{
Seksmisja - mitologizacja ról płciowych w reklamach perfum. Analiza komparatystyczna
}

Jak pisze Dana Thomas, perfumy to najbardziej dostępny i najbardziej wymowny produkt luksusowy. Perfumy pełnią rolę wprowadzenia do reszty marki; łatwo przekraczają granice, kultury i grupy konsumenckie. Są więc niezwykle ważnym elementem haute couture ${ }^{1}$. Autorzy przedłożonego tekstu zakładają, że istnieją dwie na pozór sprzeczne motywacje konsumenckie prowadzące do wyboru konkretnych perfum. Mają one za zadanie dopełniać obecny wizerunek odbiorcy - a właściwie to, jak on sam siebie postrzega (autowizerunek) - lub wspierać tworzenie takiego, który jest przez niego pożądany. Ten schemat zakupowy sprawia, że w tworzeniu reklam perfum duży nacisk kładzie się na nakreślenie spójnego wizerunku odbiorcy, by ten mógł się z nim identyfikować bądź do niego aspirować. W tym kontekście analiza ról płciowych proponowanych przez reklamy perfum stwarza możliwość wnioskowania na temat wyobrażeń kobiet i mężczyzn, które są stale obecne w medialnym dyskursie, cały czas zyskując popularność. Analiza jest też okazją do zastanowienia się nad zależnościami między rolami poszczególnych płci oraz zadania pytania, czy w tym systemie wzajemnych oddziaływań kobieta lub mężczyzna mogą egzystować samoistnie.

${ }^{1}$ D. Thomas, Luksus. Dlaczego stracił blask, Warszawa 2010, s. 141. 
Kwestia ta zasługuje na uwagę, ponieważ mity kobiecości i męskości wykorzystywane w reklamach nie tylko na swój sposób odzwierciedlają wartości wyznawane przez społeczeństwo; reklamy to również narzędzie do promowania konkretnych wzorców mających prowadzić do określonych zachowań konsumenckich, a więc w ostateczności zmieniać lub utrwalać sposób myślenia odbiorców. Rose komentuje rozważania Williamson na temat mechanizmu działania reklam, pisząc: „Reklamy zapraszają nas »bez żadnego przymusu« do tworzenia nas samych zgodnie z tym jak już wcześniej zostaliśmy przez nie stworzeni”"2.

Takie poczucie twórczej swobody to najbardziej wyrafinowana forma ideologii reklamy, [...] ponieważ tworzy w nas złudzenie, że możemy wybrać własną pozycję społeczną, za pomocą tego, co konsumujemy. Wybór jest złudzeniem [...] z tego powodu, że reklamy opierają się na kodach i systemach odniesień, które bardzo precyzyjnie wyznaczają zakres naszych możliwości interpretacyjnych ${ }^{3}$.

Stawia również założenie, że ideologia jest swojego rodzaju wiedzą, która konstruowana jest po to, aby legitymizować nierówności społeczne $e^{4}$. Odnosi się to do tezy Goldmana, że odbiorcy bezrefleksyjnie chłoną komunikowane w reklamach założenia dotyczące porządku społecznego i nie odnajdują w nich znamion ideologii. Jako przyczynę wskazuje on rutynowy odbiór wszechobecnej reklamy ${ }^{5}$. Oznacza to, że skrupulatnie skonstruowane komunikaty reklamowe odnoszą się i równie silnie wpływają na niekomercyjne dziedziny życia społecznego. Mogą mieć zatem istotne znaczenie w budowaniu postaw i samookreślaniu się poszczególnych odbiorców.

Prezentowane badanie ma na celu analizę mitów kobiecości i męskości przedstawionych $\mathrm{w}$ reklamach perfum oferowanych przez sklepy internetowe najpopularniejszych w Polsce sieci perfumerii - Sephory oraz Douglasa. Analiza stanowi część długofalowego projektu badawczego mającego odpowiedzieć na pytanie, w jaki sposób konstruowane są schematy ról płciowych w obszarze dyskursu komunikacji perfum designerskich, czyli tworzonych przez znane domy mody z segmentu haute couture ${ }^{6}$. W ramach projektu weryfikowane są one wewnątrz wyznaczonych kategorii oraz w korelacji między nimi. Podstawę do przedstawionej analizy stanowi koncepcja mitów codzienności Rolanda Barthesa. Autorzy przyglądają się nowej formie mitopodobnej - mitologii codziennej, wywodzącej się z kultury masowej, mającej wpływ na codzienne wybory i decyzje. Na tej podstawie szukają

2 J.M. Williamson, Decoding Advertisments: Ideology and Meaning in Advertising, Londyn 1978; cyt. za: G. Rose, Interpretacja materiałów wizualnych. Krytyczna metodologia badań nad wizualnościa, Warszawa 2015, s. 127.

${ }^{3}$ G. Rose, op. cit., s. 127.

${ }^{4}$ Ibidem, s. 102.

${ }^{5}$ R. Goldman, Reading Ads Socially, Londyn 1992, s. 1.

${ }^{6}$ Jednym ze sposobów typizacji perfum jest podział podług producenta — znawcy wyróżniają perfumy sieciówkowe, perfumy designerskie (znane domy mody) oraz niszowe, por. D. Thomas, op. cit. 
powtarzających się wzorców i schematów postrzegania i kreowania kobiecości oraz męskości.

Barthes definiuje mit jako „słowo”, dopowiada jednak, że „słowo jest komunikatem. Może więc nie mieć w ogóle ustnego charakteru; może przybrać formy pisane albo przedstawienia" ${ }^{7}$. Określa to mianem "mowy mitycznej”. Zaznacza też, że mit nie jest ideą ${ }^{8}$. Jednak autorzy przedłożonej pracy zakładają, że w przypadku komunikatów reklamowych mit staje się narzędziem forsowania pewnych ideologii. Jako że jego przedstawienie konstruowane jest, by spełniać tę funkcję, w tym wypadku forma (będąca wszak esencją mitu) zaczyna reprezentować idee. Warto dodać, że Jung, choć posługuje się odmienną terminologią i bada zjawisko z innej perspektywy badawczej, pisząc o „archetypach” częściowo podziela rozważania Barthesa o mitach. Mówi bowiem: "co i rusz spotykam się z nieporozumieniem polegającym na tym, że archetypy to coś określonego pod względem treści, czyli coś w rodzaju nieświadomych »wyobrażeń«. Trzeba tu zatem raz jeszcze podkreślić, że archetypy określane są

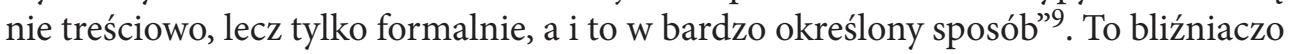
podobne stwierdzenie do słów Barthesa mówiącego: „istnieją formalne granice mitu, a nie ma substancjalnych" ${ }^{\prime 10}$. Dla zachowania przejrzystości wywodu, autorzy posługują się jednak określeniami „mit” i „mitologia” oraz „rola płciowa”. Na okoliczność niniejszego artykułu zostają one uznane za tożsame.

Materiał badawczy stanowią reklamy wód toaletowych, perfumowanych i kolońskich oraz esencji perfum (dla ułatwienia określanych w tej pracy jako perfumy lub zapachy), znajdujące się w ofercie sklepów internetowych Sephora oraz Douglas. Poszczególne zapachy zostały inicjalnie skategoryzowane według płci (damskie, męskie, „unisex”) ${ }^{11}$. Sklep Douglas w swoim internetowym katalogu nie posiada sekcji unisex, więc kategoryzację uzupełniono, wykorzystując dane z portalu Fragrantica, perfumiarskiej internetowej encyklopedii. Każdemu z zapachów przypisano odpowiadającą reklamę typu print ${ }^{12}$. Dobór ten miał charakter losowy, Z uwzględnieniem preferencji obrazów reklamujących tylko jeden zapach. Z próby wykluczono również te reklamy, na których nie pojawiają się postacie. W ten sposób zbudowane archiwum badawcze zawierało 545 reklam. Udział poszczególnych kategorii przedstawia wykres poniżej. Procentowa dystrybucja kategorii i mitów została zaokrąglona do góry, do pełnych liczb. Nie wpływa to na wynik badania,

\footnotetext{
7 R. Barthes, Mitologie, Warszawa 2008, s. 240.

${ }^{8}$ R. Barthes, op. cit., s. 239.

9 C.G. Jung, Archetypy i nieświadomość zbiorowa, Warszawa 2011, s. 91.

${ }^{10}$ R. Barthes, op. cit., s. 239.

11 To jedna z głównych kategorii różnicujących zapachy w sklepach stacjonarnych i internetowych.

12 Reklamy typu print (występujące w gazetach i magazynach) często funkcjonują też w przestrzeni internetowej jako regularna reklama wizualna.
} 


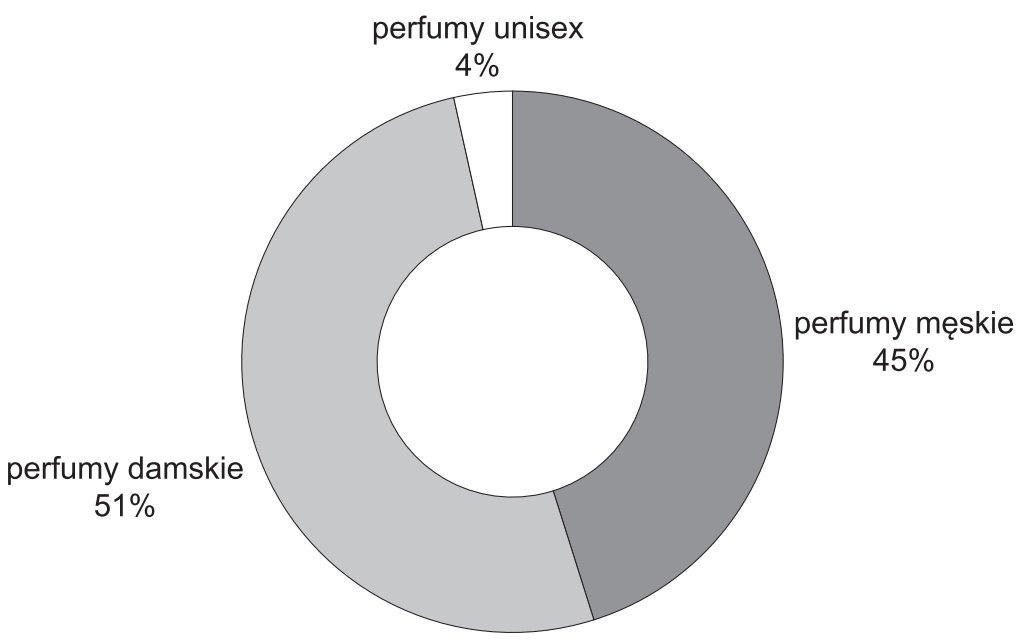

Wykres 1. Udział w archiwum badawczym reklam perfum dedykowanych dla poszczególnych płci Źródło: opracowanie własne.

bowiem wartości procentowe wykorzystywane są do komparatystyki oraz jako przyczynek do dalszej analizy.

Metodę badawczą wykorzystaną $\mathrm{w}$ tym etapie projektu stanowi analiza zawartości połączona $\mathrm{z}$ analizą semiotyczną. Na potrzeby niniejszej pracy prezentowane są przede wszystkim wyniki analizy semiotycznej. Autorzy wzięli pod uwagę liczne elementy składowe reklamy, takie jak: rozplanowanie przestrzenne, podpisy (m.in. slogany i claimy), typografię, zapadki (produkt ukazany w określonych ramach), sposób przedstawienia (np. fotografia) czy pojawienie się określonych znaczących. Wskazane składowe kodów i systemów odniesień posłużyły do rekonstrukcji kategorii mitów kobiecości i męskości, prezentowanych w analizowanych reklamach. Poniżej pokrótce zostanie scharakteryzowana mitologiczna siatka interpretacyjna, którą autorzy wyekstrahowali z badanego materiału, by w spójny sposób przeprowadzić analizę komparatystyczną.

\section{Samiec alfa}

Mit samca alfa wśród mężczyzn odwołuje się w głównej mierze do kwestii dominacji, rozumianej jako niezależność, władczość (zarówno nad innymi osobami obecnymi $\mathrm{w}$ reklamie, jak i władczość per se - podkreślona przez wykorzystanie typowych, w obrębie danych kultur, dla niej atrybutów) oraz wyższość (wyższość dosłowna, czyli umieszczenie męskiej sylwetki w centrum, podkreślenie dysproporcji między mężczyzną, a towarzyszącą mu kobietą, oraz wyższość rozumiana jako dys- 
proporcja statusu czy kapitału w rozumieniu Bourdieu ${ }^{13}$ - vide mężczyzna ubrany w elegancki garnitur, trzymający nagą kobietę). Mit samca alfa bezpośrednio wpływa również na wygląd mężczyzny - musi on bowiem także w tym aspekcie podkreślać swoją dominację. Mężczyzna będzie więc świetnie zbudowany, umięśniony (widoczne cechy atletycznej sylwetki, częste przedstawienie półnagich postaci), lub dobrze ubrany (elegancki, czarny bądź granatowy garnitur, biała bądź błękitna koszula), co substytuuje budowę ciała - spada ona na drugi plan.

\section{Gentleman}

Kategoria mitologiczna nazwana gentlemanem przedstawia mężczyznę znacznie mniej dominującego. Gentleman dominację pozornie zamienia na służbę kobiecie, którą osłania parasolem przed deszczem bądź zabiera w podróż samochodem. Mit wpływa na kompozycję reklamy oraz dobór środków wizualnych — mężczyzna nie zawsze jest postacią centralną, nie pojawia się również podkreślenie jego wyższości. Gentleman wygląda elegancko (wymienione już wcześniej garnitury i koszule) i często uśmiecha się do kobiety — warto nadmienić, że uśmiech rzadko pojawia się w przypadku innych mitów.

\section{Heros}

Mit herosa bezpośrednio odwołuje się do antycznego, klasycznego odpowiednika, choć nie można powiedzieć, że go powiela. Na uwagę zasługuje dobór modela każdy heros posiada twarde, wyraźnie zarysowane rysy twarzy. Nie bez znaczenia jest również wzrok — przenikliwe spojrzenie, skierowane prosto w obiektyw aparatu. Dominacja jest w przypadku herosa milcząca — nie jest wyrażona bezpośrednio.

\section{Bożyszcze}

Mit bożyszcza charakteryzuje uniwersalny obiekt westchnień i podziwu. Kwestią drugorzędną jest to, kto ów podziw okazuje - bożyszcze bywa podziwiane przez kobiety, mężczyzn, siebie samego. Wizerunek (a więc ciało, ewentualnie domniemany intelekt i inne cechy, które można podziwiać) jest więc dla niego wartością autoteliczną. Mężczyzna lub kobieta, realizujący mit bożyszcza, najczęściej przedstawieni są półnago. Zazwyczaj patrzą w przestrzeń, z głową odwróconą od drugiej osoby obec-

13 Por. P. Bourdieu, The forms of capital, [w:] Handbook of Theory and Research for Sociology of Education, red. J.G. Richardson, Nowy Jork 1986, s. 241-258. 
nej w reklamie, niejako dając się wielbić i podkreślając pozorny dystans, jaki istnieje między nimi. Widoczna jest także autoafirmacja seksualności bożyszcza. Opis mitu charakteryzuje zarówno mężczyznę, jak i kobietę.

\section{Buntownik/Buntowniczka}

Mit buntownika/buntowniczki to mit uniwersalny; w analizowanych materiałach nie jest determinowany przez cechy płciowe, a więc opis mitu charakteryzuje zarówno mężczyznę, jak i kobietę. Mit buntownika konstruowany jest przez odwoływanie się do subkultur (np. punk) i wykorzystywanie atrybutów im kulturowo przypisanych (skórzana ramoneska, mocny, charakterystyczny makijaż) lub celowe kontestowanie norm społecznych (co jest w gruncie rzeczy również immanentną cechą subkultur). Ilustruje to na przykład reklama przedstawiająca napad na bank.

\section{Opiekun}

Mit opiekuna to mit uniwersalny. Pojawia się co prawda nawiązanie do cech płciowych (kobieta-matka, mężczyzna-ojciec), ale proporcje są równo rozłożone, więc opis mitu charakteryzuje zarówno mężczyznę, jak i kobietę ${ }^{14}$. Mit opiekuna jest pozbawiony dominacji. Opiekunowi, niezależnie od płci, często towarzyszą dzieci. Jeśli pojawia się kontakt fizyczny (obejmujące się postaci), również nie niesie on znamion zamierzonej dominacji - świadczy raczej o empatii względem drugiej osoby.

\section{Bezimienny przedmiot seksualny}

Mit bezimiennego przedmiotu seksualnego to mit uniwersalny. W analizowanych materiałach nie jest determinowany przez cechy płciowe, a więc opis mitu charakteryzuje zarówno mężczyznę, jak i kobietę. Mit bezimiennych opisuje przedmiot seksualny, który pozbawiony jest cech wyróżniających - nie jest ważne, kim dana postać jest, bowiem pełni rolę symbolicznej nagrody dla drugiej osoby. Konotacje seksualne są tutaj kluczowe, bowiem bezimienny przedmiot seksualny najczęściej przedstawiany jest nago, często z twarzą widoczną tylko częściowo. Nierzadko pojawiają się też przedstawienia bez twarzy — obraz kadrowany jest tak tak, by nie była widoczna, lub zostaje czymś zasłonięta. Bezimienny przedmiot seksualny jest w pełni poddany i zdominowany przez drugą osobę.

${ }^{14}$ Mimo uniwersalności, nazwa zarówno męskiego jak i kobiecego mitu celowo wyrażona jest w rodzaju męskim. Autorzy pragnęli uniknąć konkretnych konotacji słowa „opiekunka”, które znaczeniowo nie są tożsame z mitem. 


\section{Zwyczajny/zwyczajna}

Mit Zwyczajnego/zwyczajnej to mit uniwersalny. Pojawia się w ramach niego co prawda nawiązanie do cech płciowych, ale proporcje są równo rozłożone, więc opis mitu charakteryzuje zarówno mężczyznę, jak i kobietę. Ich naturę dobrze oddaje angielskie określenie casual ${ }^{15}$. Zwyczajni są zwykli: brak im charakterystycznych, wyrazistych cech płciowych i osobowościowych. Są przedstawiani najczęściej w roli partnerskiej i stanowią dopełnienie drugiej osoby, często podobnej do nich wizualnie (sylwetka, ubiór, estetyka). W przypadku tego mitu nie pojawiają się konotacje seksualne.

\section{Jeden/jedna z wielu}

Mit jednego/jednej z wielu to mit uniwersalny. Pojawia się co prawda nawiązanie do cech płciowych, ale proporcje są równo rozłożone, więc opis mitu charakteryzuje zarówno mężczyznę, jak i kobietę. Mit ten różni się od mitu bezimiennego przedmiotu seksualnego przede wszystkim brakiem wyraźnych i determinujących konotacji seksualnych i dominacyjnych. Jeden z wielu stanowi tło dla towarzyszącej mu osoby. Znacząca staje się tylko jego obecność, a konkretne cechy, którymi emanuje, nie są istotne dla jego wizerunku. Jeden $\mathrm{z}$ wielu konstytuuje więc osobę, z którą jest przedstawiony — podkreśla jej cechy mitologiczne, współtworzy jej mit oraz jest swojego rodzaju gratyfikacją (symbolizuje powodzenie u płci przeciwnej po zastosowaniu danego zapachu). Należy podkreślić, że to mit, który nigdy nie występuje prymarnie ${ }^{16}$.

\section{Samica alfa}

Mit samicy alfa jest kobiecym odpowiednikiem samca alfa. Większość ich cech jest tożsama - pojawia się więc wyraźna dominacja, władczość oraz wyższość. Co warte podkreślenia, samica alfa jest również często wyższa od swojego partnera, dzięki wykorzystaniu perspektywy lub kadrowania. Samica alfa często dotyka mężczyzny, z którym jest przedstawiona i przez dotyk go kontroluje (dominacja), pokazując, na co może sobie pozwolić. Występuje ubrana albo w bardzo erotyczny sposób (suknie, podkreślające i odsłaniające kobiece atrybuty), nago, lub jest niejako "przebrana” za mężczyznę.

15 Wchodzące w niezmienionej, nieprzetłumaczonej formie do języka polskiego, więc użyte w tekście w oryginale.

${ }^{16}$ A więc jako mit męski w reklamach perfum męskich i mit damski w reklamach perfum damskich. 


\section{Bogini}

Mit bogini zdaje się być mutacją mitu bożyszcza. Dotyczy tylko kobiet i opisuje obiekt uwielbienia, ale i respektu, nierzadko połączonego ze strachem. Kobieta realizująca mit bogini jest przedstawiana jako władcza, często w kolorach kojarzących się z bogactwem (złoto, srebro). Jej skóra lśni nienaturalnym blaskiem, jednoznacznie wskazując, że nie jest to zwykła śmiertelniczka. Bogini czasem towarzyszy grupa mężczyzn rywalizujących o jej względy.

\section{Uwodzicielka}

Kobieta realizująca mit uwodzicielki dzieli pewien zestaw cech z samicą alfa - jest bezpośrednia i dominująca. Odróżnia ją jednak celowość wykonywanych działań - podczas gdy samicy alfa zależy na podkreśleniu supremacji, uwodzicielka kusi w sposób jawnie seksualny. Wykorzystując eksponowane atuty swojego ciała (rozświetlone nogi, odsłonięte piersi, wydatne usta), stara się uwieść mężczyznę.

\section{Super dziewczyna}

Mit super dziewczyny charakteryzuje kobietę, której nadrzędnym celem jest dobra atmosfera w związku. Dzieli pasje z mężczyzną i docenia jego starania. Nie wchodzi w seksualne interakcje, chociaż nic nie stoi na przeszkodzie, żeby tak było.

\section{Sensualna}

Mit kobiety sensualnej stoi pomiędzy mitem romantyczki i uwodzicielki. Kobieta sensualna nieśmiało uwodzi, ale też chce być uwodzona. Prowadzi grę niuansów - zamiast bezprecedensowo wykorzystywać kobiece atrybuty (nogi, piersi, usta), posługuje się delikatnym uśmiechem i przenikliwym, intrygującym spojrzeniem. $\mathrm{W}$ miarę niebezpieczeństwa może się więc zawsze wycofać.

\section{Księżniczka}

Mit księżniczki niejako nawiązuje do kobiety sensualnej. Księżniczka często daje przyzwolenie by adorować ją czynami - daje się obejmować, otaczać, osłaniać parasolem. W porównaniu do kobiety sensualnej księżniczka nie wykorzystuje kobiecych 
atrybutów, nawet tych mniej oczywistych (uśmiech, spojrzenie). Zdaje sobie sprawę z tego, jak odbiera ją mężczyzna i pozwala mu działać - często w sposób (pozornie) pasywny. Pozornie, bowiem swój cel osiąga.

\section{Romantyczka}

Mit romantyczki jest przedstawieniem zwiewnej, często delikatnej, kobiety (w opozycji chociażby do samicy alfa). Kobietę romantyczkę od kobiety sensualnej odróżniają detale - nieśmiały uśmiech i konkretne atrybuty (np. kwiaty). Romantyczka nie wchodzi w bezpośrednie, seksualne interakcje z mężczyznami - jej seksualność nie jest widoczna.

Należy podkreślić, że analizowane reklamy zawierają elementy polisemiczne, dlatego $\mathrm{w}$ procesie przyporządkowania im konkretnego mitu autorzy pracy musieli zdecydować, który z nich wybija się na pierwszy plan. To, że reklamy nie odnoszą się tylko do jednej mitologii ma trzy esencjonalne przyczyny. Pierwszą z nich jest wspomniany wcześniej brak substancjalnych granic mitu. Druga odnosi się do założenia, że wszystko może być mitem, ponieważ „każdy przedmiot na świecie może przejść $\mathrm{z}$ istnienia zamkniętego, niemego, $\mathrm{w}$ stan podatny na zawłaszczenie przez społeczeństwo" ${ }^{17}$. Oczywistym zdaje się zatem, że niektóre sfery poszczególnych mitologii kobiecości i męskości będą się przenikać. W dalszej części pracy zobrazowane zostanie również, że występowanie części wspólnych ma miejsce nie tylko w ramach tej samej płci. Trzeci powód występowania kilku mitów w jednym wyobrażeniu wiąże się z funkcjami reklamy. Dzięki multiplikacji prezentowanych wzorców jej komunikat dociera do szerszego grona odbiorców, utożsamiających się lub preferujących określone role płciowe. Poniżej przedstawiono udział opisanych wcześniej mitologii w reklamach perfum dedykowanych tej samej płci.

Najczęściej reprezentowanymi kobiecymi mitologiami w reklamach perfum damskich okazały się samica alfa oraz bożyszcze (po 21\%). Następnym najczęściej ukazywanym mitem jest opiekunka, której udział w całości reklam jest prawie o połowę mniejszy (12\%). Prawie tak samo często pojawiają się bogini, romantyczka i buntowniczka (po 9\%). Super dziewczyna i kobieta sensualna reprezentowane są stosunkowo rzadko (po 6\%), a najrzadziej spotykane są kobieta zwyczajna i uwodzicielka (po 3\%). Kategoria „inne” to również 3\% analizowanych reklam — do kategorii należą reklamy, które nie zawierały zdiagnozowanych mitów. Mitologie najczęściej odczytywane w tej części materiału badawczego (samica alfa oraz bożyszcze) to kobiety, którym podporządkowuje się otoczenie. Co prawda skojarzenie $\mathrm{z}$ dominacją jest oczywiste w przypadku samicy alfa, ale bożyszcze to także postać, charakteryzująca się tą cechą. Zostało

17 R. Barthes, op. cit., s. 239. 


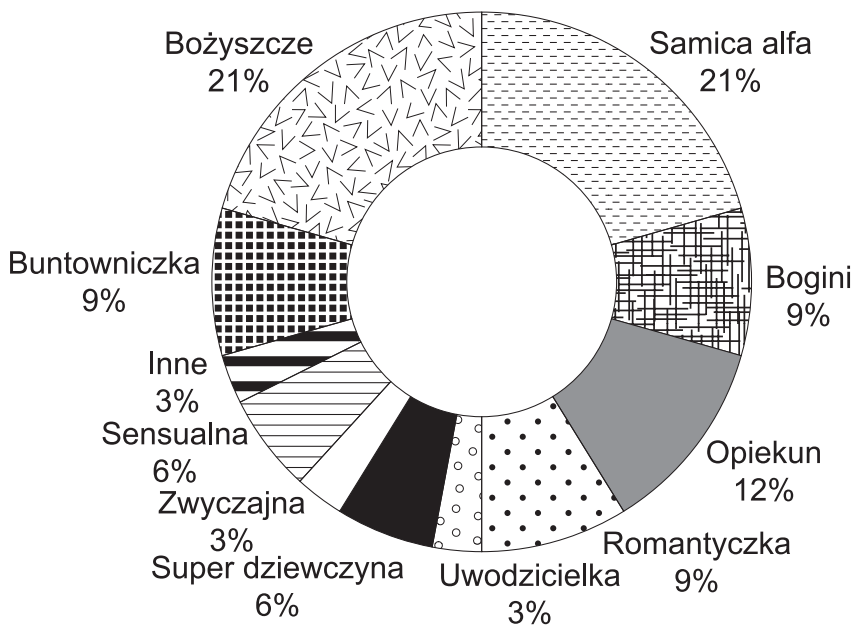

Wykres 2. Udział wyszczególnionych kobiecych mitologii w analizowanych reklamach perfum damskich

Źródło: opracowanie własne.

to szerzej zobrazowane w dalszej części pracy. Dominacja jest pośrednio skorelowana również z uwodzicielką. Wymienione mity stanowią razem $45 \%$ napotkanych kobiecych ról, a po dodaniu udziału kobiety sensualnej (która jest raczej neutralna pod tym względem) to w sumie 50\%. Wynika $\mathrm{z}$ tego, że tylko połowa reklam perfum damskich promuje wrażliwe społecznie role kobiece. Kłóci się to z tradycyjnie postrzeganą kobiecością. Warto zwrócić też uwagę, że tak licznie reprezentowana samica alfa to w gruncie rzeczy kobieta posiadająca tradycyjnie męskie cechy. Jej wizualne formy pozbawiane są często cech znaczących nawiązujących do kobiecości, takich jak długie rozpuszczone włosy lub typowo damskie ubranie. Można stwierdzić, że w ten sposób uwidacznia się w niej animus, czyli „męska personifikacja nieświadomości”" ${ }^{18}$, przyjmująca formę „świętego przekonania”, „Kiedy takie przekonanie głoszone jest donośnym i nalegającym głosem lub gdy narzuca się je innym [...] to łatwo rozpoznać w kobiecie stojącą za tym męskość [...]. Można nagle odkryć, że w kobiecie spotykamy się z czymś, co jest zawzięte, zimne i zupełnie nieprzystępne" 19 - słowa Junga objaśniającego fenomen animusa zdają się dookreślać definicję samicy alfa.

Prezentowany wykres pokazuje, że rozkład udziału mitów jest dość różnorodny i stosunkowo wyważony. Co więcej, w badanym materiale znajdowały się reklamy zapachów na różne okazje i pory (np. na dzień i na noc). Z badania tej grupy reklam płynie wniosek, że konsumentka designerskich perfum ma pozostawioną dużą wolność w wyborze tego, kim jest lub chce być. Wolność ta jest tak dalece posunięta, że

18 C.G. Jung, Człowiek i jego symbole, Katowice 2018, s. 260.

19 Ibidem. 


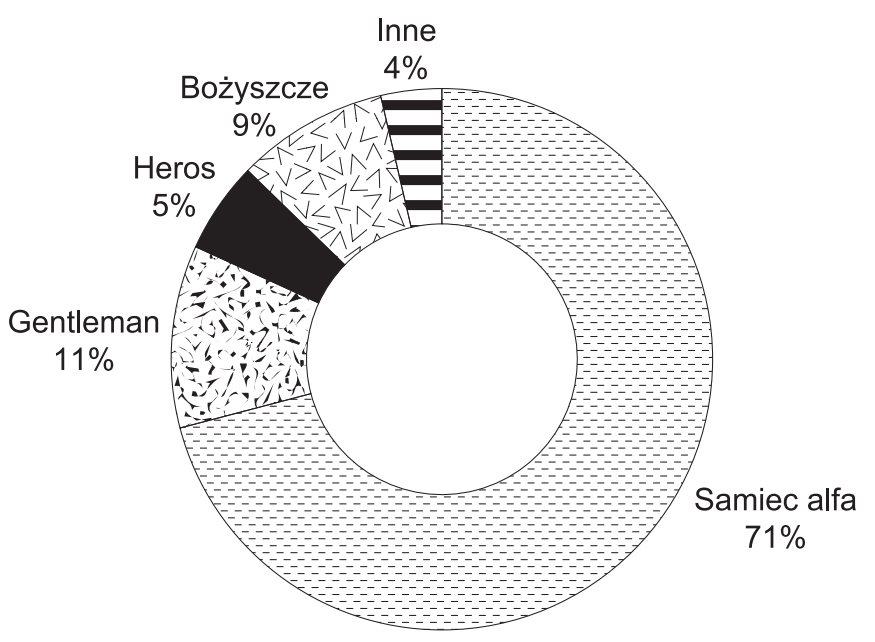

Wykres 3. Udział wyszczególnionych męskich mitologii w analizowanych reklamach perfum męskich

Źródło: opracowanie własne.

możliwym wyborem jest nawet całkowita rezygnacja z kobiecości. Mało tego, kobieta ma możliwość przeistaczać się w zależności od pory dnia, okazji i własnej fantazji.

Udział wyszczególnionych męskich mitologii w analizowanych reklamach perfum męskich (wykres 3) już na pierwszy rzut oka znacząco różni się od udziału damskich mitologii w reklamach perfum damskich (wykres 2). Pierwszą, zasadniczą różnicą jest wyekstrahowanie jedynie czterech mitów męskości. Najczęściej występującą rolą, analogicznie do przypadku reklam zapachów kobiecych, jest samiec alfa. Pojawia się on jednak ponad trzy razy częściej niż jego kobiecy odpowiednik i stanowi zdecydowaną większość w badanej grupie (71\%). Zauważyć można zatem, że, w przeciwieństwie do kobiet, mężczyźni nie mają tak jednoznacznego przyzwolenia na rezygnację z cech tradycyjnie przypisywanych swojej płci. Drugą najczęściej (choć siedem razy rzadziej od samca alfa) reprezentowaną mitologią męską jest gentleman (11\%). Mit ten jest raczej transparentny osobowościowo, a jego esencją jest spełnianie oczekiwań społecznych związanych $\mathrm{z}$ właściwym zachowaniem i kulturą osobistą oraz przyjmowanie konkretnej postawy wobec kobiet. $Z$ kolei bożyszcze to mężczyzna, u którego, analogicznie do samicy alfa, na pierwszy plan wybijają się cechy kobiece. Uzewnętrzniają się one m.in. w delikatnych rysach twarzy czy nieobecnym spojrzeniu. Bożyszcze nie reprezentuje jednak wcześniej wspomnianej cechy, jaką jest wrażliwość społeczna. Przeciwnie - jest swojego rodzaju narcyzem, którego wyjątkowość potwierdza ignorowane otoczenie. Najmniej licznie spotykany w tej części materiału badawczego jest heros (5\%). Kategoria „inne” jest w przybliżeniu tak samo liczna (4\%), jak w przypadku mitologii kobiecych w reklamach perfum damskich. Analogicznie zawiera ona reklamy, które nie poddały się nałożonym ramom interpreta- 
cyjnym lub ich interpretacja była wyraźnie dyskusyjna. Z przedstawionego wykresu wysnuć można wnioski, że odbiorcy męskich perfum designerskich mają znacznie ograniczony wybór jeśli chodzi o kształtowanie siebie. Dodatkowo, zarówno w przypadku reklam zapachów męskich, jak i damskich, dominacja jest nastawieniem, na które kładziony jest duży nacisk. Może to oznaczać, że w świecie konstruowanym przez modę siła wykorzystywana w opozycji do otaczającego społeczeństwa jest cechą pożądaną.

Żeby odpowiedzieć na pytanie, jaki wpływ mają na siebie role kobiece i męskie, należy przyjrzeć się temu, jakie mity kobiecości występują w reklamach perfum męskich i na odwrót. Poniżej znajdują się także mitologie męskie, które pojawiają się w reklamach perfum damskich, a nie odnotowano ich wcześniej w kontekście męskich zapachów i nie zostały dotychczas poruszone w analizie.

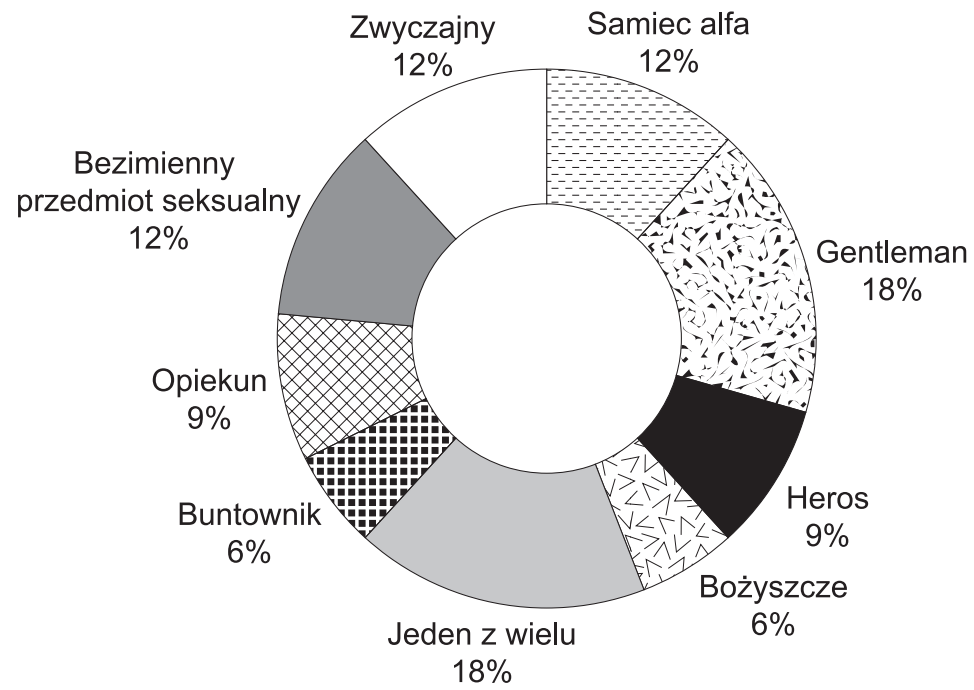

Wykres 4. Udział wyszczególnionych męskich mitologii w analizowanych reklamach perfum damskich

Źródło: Opracowanie własne.

Podobnie jak w przypadku kobiecych, udział męskich mitologii zawartych w reklamach damskich zapachów rozkłada się relatywnie równomiernie. Co interesujące, pojawia się tu aż pięć nowych mitów męskości, które nie miały racji bytu w reklamach perfum męskich. Sugeruje to, że kobiety będące adresatkami komunikatów związanych z zapachami damskimi mają nie tylko szeroki i wolny wybór na temat ról, którymi same są zainteresowane. Mają także legitymację do pożądania i oczekiwania od mężczyzn spełnienia różnych ról, paradoksalnie nawet takich, z którymi nie zostają nawet zaznajomieni poprzez skierowane do nich reklamy. 
Autorzy pracy stawiają również pytanie o zależność między odgrywaną rolą kobiecą, a przyporządkowaną jej przez twórców reklam perfum damskich rolą męską. Sprawdzają tym samym, czy któraś mitologia kobieca współtworzona jest poprzez towarzyszącą jej konkretną mitologię męską. W tym celu z materiału badawczego wyekstrahowano reklamy, na których pojawia się zarówno postać kobieca, jak i męska. Poniższe wykresy (rys. 1) przedstawiają procentowy udział wyróżnionych ról męskich towarzyszących konkretnym rolom kobiecym. Ilustrują one wyraźnie, że większość mitologii kobiecych jest skorelowana z konkretnymi mitologiami męskimi. Należy zwrócić uwagę, że nie sposób rozstrzygnąć, czy mity kobiece definiują męskie, czy na odwrót. Łączy je bowiem skomplikowana sieć zależności. Można jednak założyć, że w większości przypadków reklam zapachów damskich, kobieca mitologia jest prymarna względem męskiej w takim sensie, że kobieca rola płciowa tworzona jest jako pierwsza. Analogicznie dzieje się w kontekście reklam zapachów męskich.

Mitologiczna kobieta sensualna występuje jedynie w towarzystwie jednego z wielu lub zwyczajnego. Jest to wart uwagi przypadek, bowiem oba mity męskie nie pojawiają się w reklamach męskich zapachów. Zdają się więc zostać niejako stworzone na potrzeby wspólistnienia z rolą kobiecą, która występuje w 6\% reklam zapachów damskich i sama w sobie jest raczej transparentną osobowościowo afirmacją piękna i młodości. Być może rola męska ma więc za zadanie nadać kobiecie sensualnej więcej charakteru. Kobiety bożyszcza i samice alfa to z kolei przykłady mitów, które występują z różnorodnymi rolami męskimi. To oczywiste, że ich moc działa na każdego. Należy natomiast podkreślić, że bożyszczu towarzyszy przede wszystkim narracja cielesności. $Z$ kolei samica i samiec alfa mogą współistnieć razem w ramach jednej reklamy, przy czym żadne z nich nie jest nadrzędne względem drugiego. Występują oni razem zarówno w sytuacji konkurowania ze sobą, jak i współdominacji. Zrozumiałym jest, że kobieta opiekun pojawia się w towarzystwie zwyczajnego oraz opiekuna, romantyczka w towarzystwie gentlemana oraz zwyczajnego, super dziewczynie towarzyszy gentleman lub heros, a buntowniczce drugi buntownik lub opiekun $^{20}$. Logika rzeczywiście nakazuje przypisać uwodzicielce bezimienny przedmiot seksualny. To, że towarzyszący jej mężczyzna nie ma jaskrawych cech wyróżniających, sugeruje, że może ona mieć każdego. Nie może to być jednak jeden z wielu, ponieważ obiera ona sobie za cel (a więc wybiera) konkretnego, a nie któregokolwiek. Zaskakujące, że z boginią nie współistnieją tylko i wyłącznie mężczyźni, którzy będą ją wielbić i bezrefleksyjnie jej służyć. Ten zabieg również wpływa na ukazanie, jak wielka jest jej moc oddziaływania. Widać więc, że w niektórych przypadkach do

${ }^{20}$ Ideologicznie podbudowany bunt potrzebuje, zdaje się, konkretnych, pragmatycznych fundamentów. 

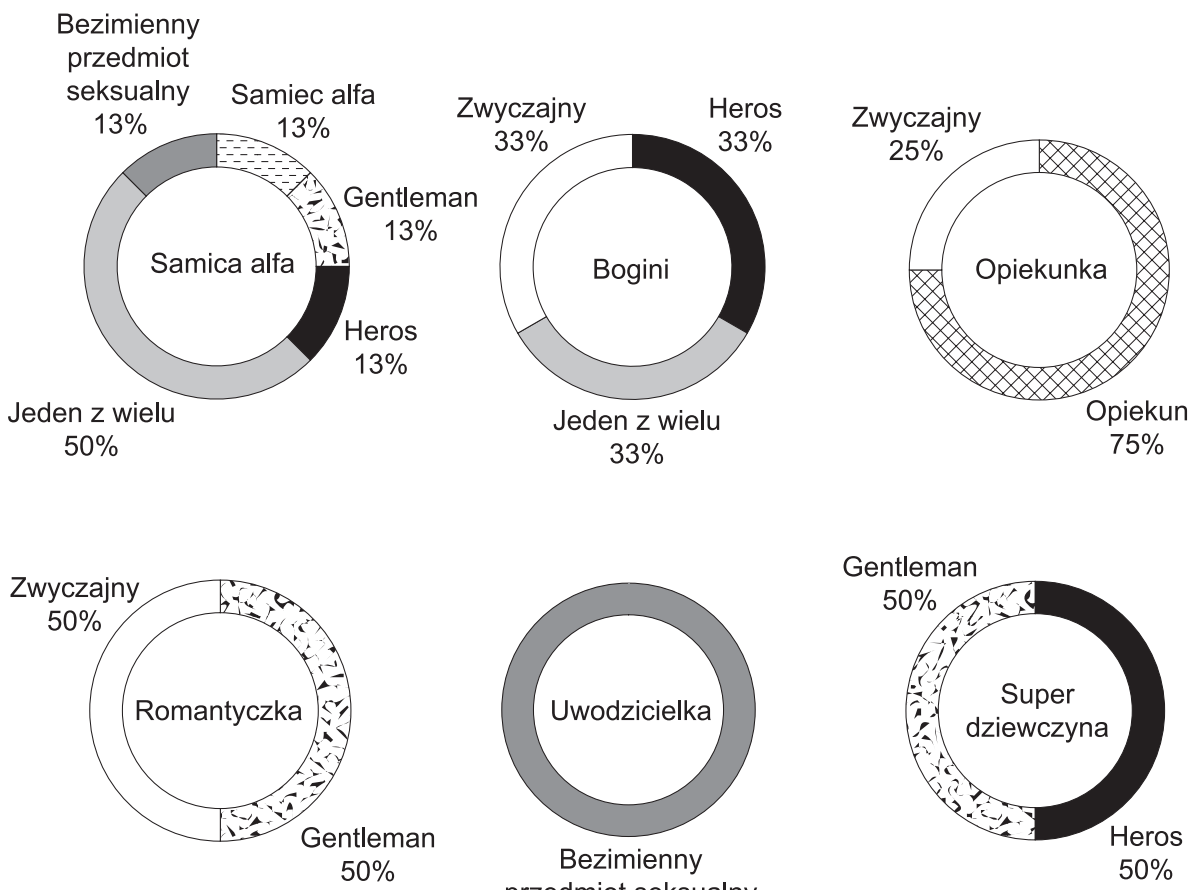

przedmiot seksualny
$100 \%$
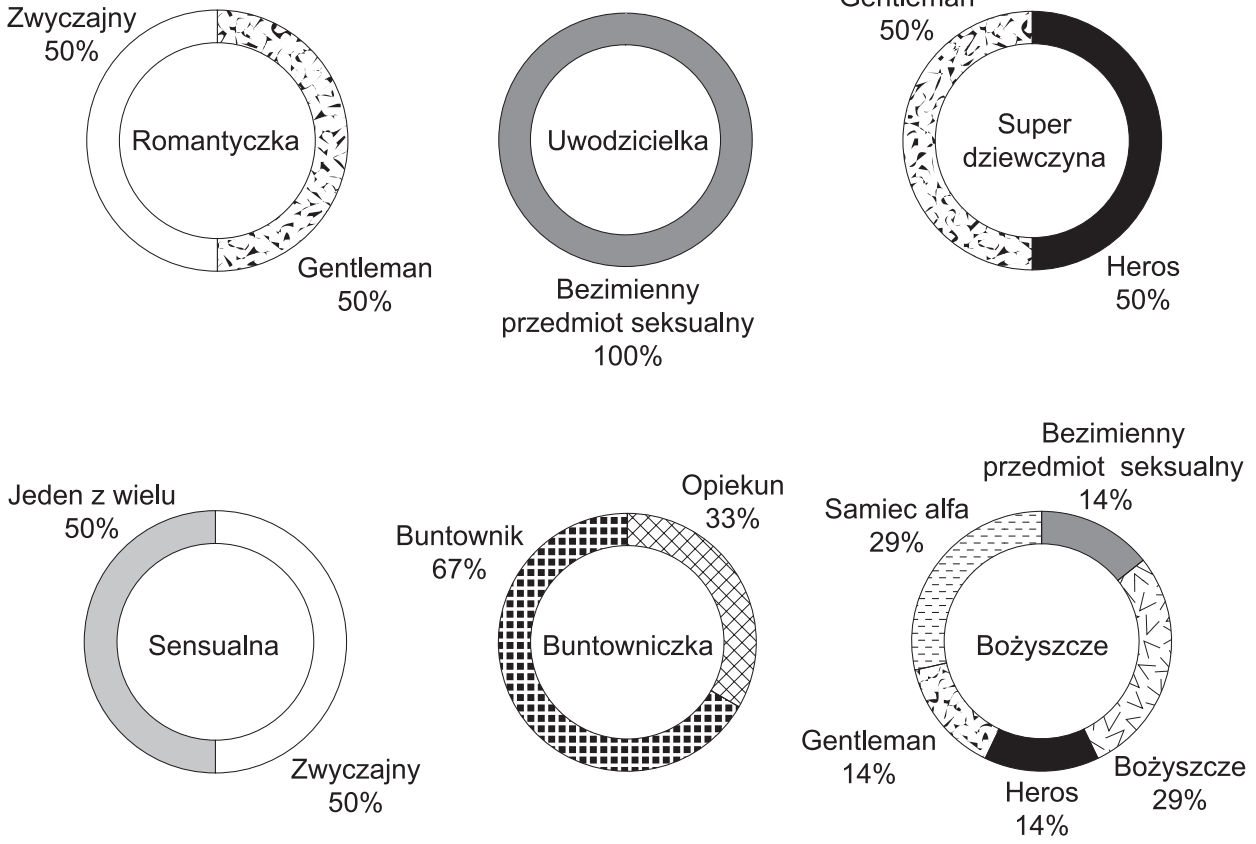

Rysunek 1. Procentowy udział wyróżnionych mitologii męskich towarzyszących konkretnym mitologiom kobiecym w reklamach perfum damskich (wykresy)

Źródło: opracowanie własne.

mitów kobiecości dobierane są po prostu komplementarne mitologie męskie, jednak w innych towarzyszące role płciowe mają za zadanie wzajemnie się konstruować.

Warto zwrócić uwagę, że kobiece mitologie pojawiające się w reklamach perfum męskich są de facto multiplikacją mitologii prezentowanych w kontekście zapachów damskich. Nowym mitem jest jedna z wielu - mit ten nie zostanie dodatkowo opisany, ponieważ jest on precyzyjną kobiecą kalką omówionego wcześniej jednego z wie- 
lu. Analogiczna sytuacja dotyczy księżniczki, która do istnienia potrzebuje, a jakże, swojego księcia. Nawet kobieta bezimienny przedmiot seksualny wystąpiła już (jeden raz) $\mathrm{w}$ przebadanym materiale perfum damskich - na wykresie 2 znajduje się ona w kategorii „inne”.

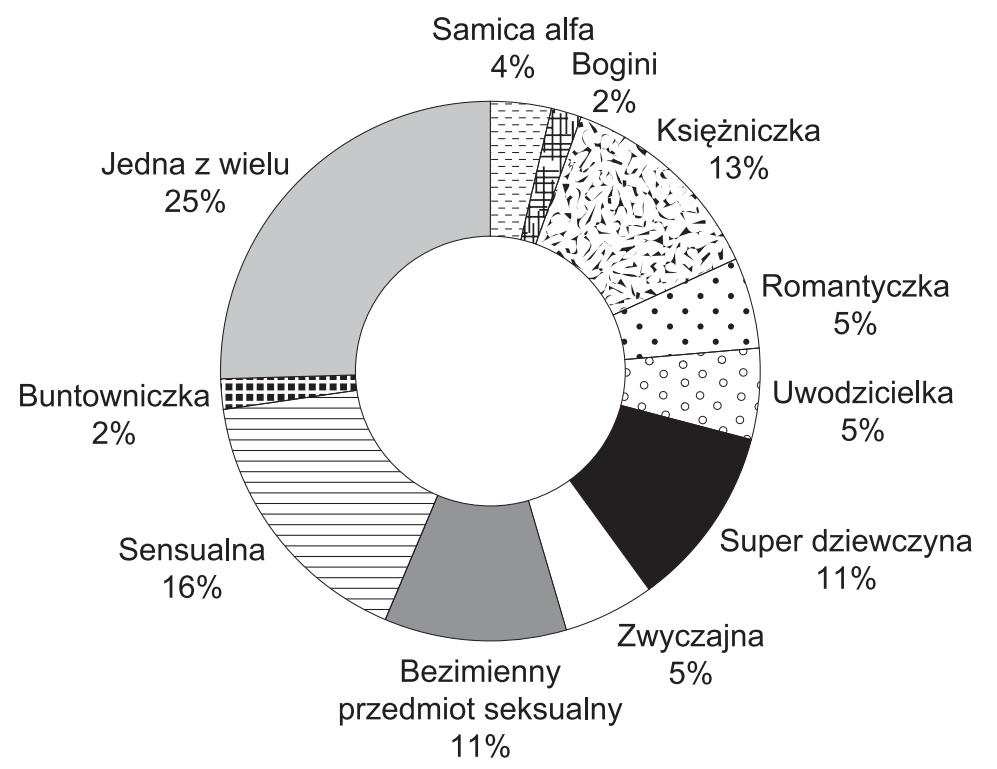

Wykres 5. Udział wyszczególnionych kobiecych mitologii w analizowanych reklamach perfum męskich (wykresy)

Źródło: opracowanie własne.

Powyższy wykres ilustruje, że w omawianym przypadku znów mamy do czynienia z dużą różnorodnością kobiecych mitologii. Klaruje się zdecydowana przewaga mitów opartych na cielesności, co nie jest szczególnie zaskakujące. Skoro w komunikatach skierowanych do mężczyzn są oni wyraźnie seksualizowani (samiec alfa występuje głównie w tym kontekście), muszą im towarzyszyć również seksualizowane kobiety. Poniższe wykresy (rys. 2) szczegółowo przedstawiają korelacje między poszczególnymi mitami męskimi, a mitami kobiecymi w reklamach perfum męskich.

Powtarza się tu tendencja, że samiec alfa może zdominować przedstawicielkę każdej mitologii. Analizując mity kobiece towarzyszące gentlemanowi, nasuwa się wniosek, że jego wizerunek tworzony jest poprzez wyeliminowanie skojarzeń silnie erotycznych. Zastanawiające, że heros zawsze współistnieje z kobietą sensualną wyjaśnień można szukać w średniowiecznym obrazie rycerza i damy serca, ale nie wydaje się to wystarczające. Męskie bożyszcze natomiast skorelowane jest $\mathrm{z}$ komplementarnymi mitologiami kobiecymi. Warto podkreślić, że chociaż mit kobiety bezimiennego przedmiotu seksualnego pojawia się znaczącą ilość razy, to współistnieje 

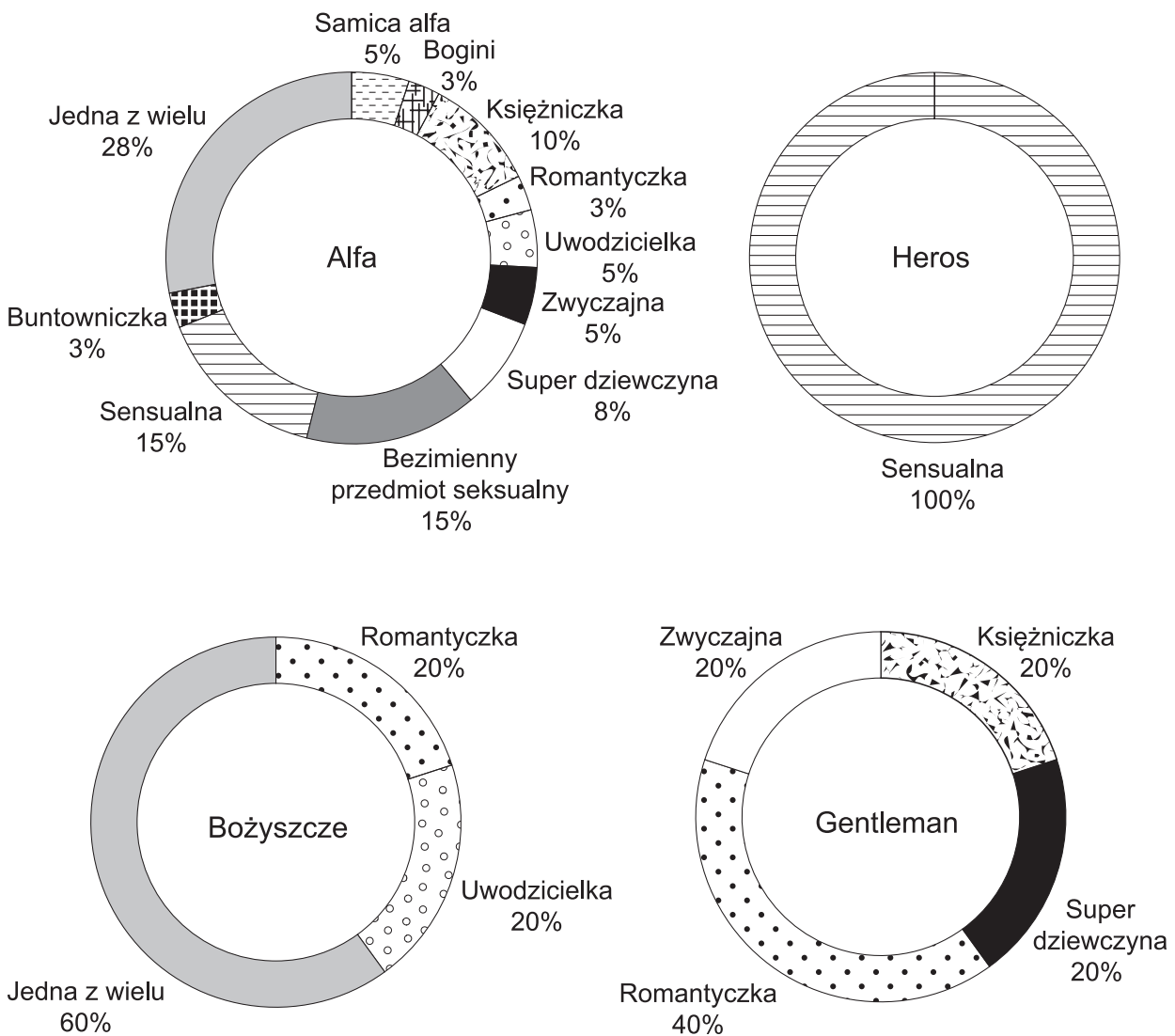

Rysunek 2. Procentowy udział wyróżnionych mitologii kobiecych towarzyszących konkretnym mitologiom męskim w reklamach perfum męskich

Źródło: opracowanie własne.

on tylko z mitem samca alfa. Mit ten zresztą z natury przejawia silne konotacje dominująco-seksualne (podtrzymuje to wizerunek około $60 \%$ towarzyszących mu kobiet). Dla podkreślenia, w przypadku zapachów damskich, mężczyzna odgrywający tę rolę koreluje aż z 3 mitami kobiecymi, w tym wspomnianą wcześniej dominującą kobietą bożyszczem. Potwierdza to wcześniejszy postulat, że reklamy perfum damskich równie szeroko, choć w inny sposób, forsują postawy oparte na dominacji.

Analiza zgromadzonego materiału wykazała, że w wizualnych reklamach perfum designerskich istnieją dwa rodzaje zależności między mitami kobiecymi i męskimi. Pierwszą z nich jest pełna komplementarność, która wzmacnia komunikat. Druga polega na współtworzeniu ról płciowych poprzez mniej oczywiste zależności. Oznacza to, że czasami mity mogą egzystować samoistnie, podczas gdy w innych przypadkach są od siebie zależne (np. nie ma gentlemana bez kobiety, którą może się za- 
opiekować). Zauważalna jest tendencja afirmacji dominacji oraz piękna i młodości, a więc cielesności, sensualności. Nie zaskakuje zatem powszechna seksualizacja zarówno kobiet, jak i mężczyzn. Kluczowym zdaje się spostrzeżenie, że obszar dyskursu komunikacji perfum designerskich jest preferencyjny i bardziej liberalny w stosunku do kobiet. Wachlarz ról proponowanych mężczyznom jest niezwykle ubogi, podczas gdy kobiety cieszą się relatywnie dużą wolnością w wyborze nie tylko kim chcą być, włącznie z możliwością częściowego porzucenia swojej kobiecości, ale też jakiego partnera pragną.

\section{Bibliografia}

Barthes R., Mitologie, Warszawa 2008.

Bourdieu P., The forms of capital, [w:] Handbook of Theory and Research for Sociology of Education, red.

J.G. Richardson, Nowy Jork 1986.

Goldman R., Reading Ads Socially, Londyn 1992.

Jung C.G., Archetypy i nieświadomość zbiorowa, Warszawa 2011.

Jung C.G., Człowiek i jego symbole, Katowice 2018.

Rose G., Interpretacja materiałów wizualnych. Krytyczna metodologia badań nad wizualnościa, Warszawa 2015.

Thomas D., Luksus. Dlaczego stracił blask, Warszawa 2010.

Williamson J.M., Decoding Advertisments: Ideology and Meaning in Advertising, Londyn 1978.

\section{Sexmission - the mythologisation of gender roles in perfume advertising. A comparative analysis}

Summary

The authors of perfume adverts put lot of emphasis on creating a consistent image of their addressees so that the addressees can identify with or aspire to them. The article is a presentation of the myth of femininity and masculinity extracted from 545 print adverts of fragrances offered by the online stores of the two biggest perfume retailers in Poland - Sephora and Douglas. The starting point of the analysis is a definition, proposed by Roland Barthes, of a new myth-like form - everyday mythology deriving from popular culture and influencing everyday choices and decisions. On this basis, drawing on a content analysis combined with a semiotic analysis, the author distinguishes patterns in the perception and creation of femininity and masculinity. The present study is an attempt to answer the question about the link between the mythologies in question as well as the questions of whether a woman can exist without a man in the reconstructed discursive space and whether she is essential to his existence.

Keywords: semiotic analysis, mythologies, perfumes, femininity, masculinity 